\title{
THE EFFECT OF CORN SILK EXTRACT (Zea mays) AS BIOLARVICIDES OF Aedes aegypti MOSQUITO LARVAE IN EFFORTS TO CONTROL SPREAD OF DENGUE HEMORRHAGIC FEVER
}

\author{
Rahmad Wahyudi' ${ }^{1}$ Harfina ${ }^{1}$, Yogi Khoirul Abror' ${ }^{1}$ \\ ${ }^{1}$ STIKes Ngudia Husada Madura \\ JL. RE Martadinata No 45, Mlajah-Bangkalan, East Java, Indonesia \\ Alamat korespondensi: Rahmad Wahyudi \\ Email: rahmadwahyudi5790@yahoo.com
}

\begin{abstract}
Dengue hemorrhagic fever (DHF) is still a serious health problem in the community. DHF is caused by the dengue virus (DENV) and is transmitted by the Aedes aegypti (Ae. aegypti) mosquito, which is the main vector for the virus. In controlling DHF vectors, larvicides are still used. These larvicides contain chemical compounds that have negative side effects affecting the human body. Therefore, there is a need for natural-based larvacides (biolarvicides). The purpose of this study was to determine the potential of corn silk as a biolarvicide against dengue vector larvae (Aedes aegypti). This study was carried out at the STIKes Ngudia Husada Madura Bangkalan Laboratory and was done by taking corn silk waste samples disposed of as waste from corn farmers and corn traders in Bangkalan Regency. A Thousand samples of Aedes aegypti larvae that had reached instar III were used and divided into five test groups, namely $0 \mathrm{~g} / \mathrm{L}$ (control), $6.25 \mathrm{~g} / \mathrm{L}, 12.5 \mathrm{~g} / \mathrm{L}, 25 \mathrm{~g} / \mathrm{L}$, and $50 \mathrm{~g} / \mathrm{L}$. Each group contained 200 larvae. The experiment was repeated 3 times. Data of the number of deaths of Aedes aegypti larvae were collected every 24 hours. The highest dose that could kill Aedes aegypti larvae was at $20 \mathrm{~g} / \mathrm{L}$.
\end{abstract}

Keywords : biolarvicides, corn silk, larvae, Aedes aegypti

\section{ABSTRAK}

Penyakit demam berdarah dengue (DBD) masih menjadi masalah kesehatan yang serius di masyarakat. Penyakit DBD disebabkan virus dengue (DENV) dan ditularkan oleh nyamuk Aedes aegypti (Ae. aegypti) sebagai vektor utama. Selama ini dalam pengendalian vektor DBD masih menggunakan larvasida yang mengandung senyawa kimia yang memiliki efek samping bagi tubuh manusia, maka dari itu perlu adanya larvasida berbahan dasar alam (biolarvasida). Tujuan dari penelitian ini adalah untuk mengetahui potensi rambut jagung sebagai biolarvasida terhadap jentik vektor demam berdarah dengue (Aedes aegypti). Penelitian ini akan dilaksanakan di Laboratorium STIKes Ngudia Husada Madura Bangkalan dengan mengambil sampel limbah rambut jagung dari petani jagung dan pedagang jagung yang berada di Kabupaten Bangkalan yang dibuang sebagai limbah. Digunakan 1000 sampel $l$ arva Aedes aegypti yang telah mencapai instar III, dibagi menjadi 5 kelompok uji yaitu $0 \mathrm{~g} / \mathrm{L}$ (kontrol), 6,25 g/L, 12,5 g/L, $25 \mathrm{~g} / \mathrm{L}$, dan $50 \mathrm{~g} / \mathrm{L}$. Masing-masing kelompok berisi 200 larva. Pengulangan percobaan dilakukan selama 3 kali. Data diperoleh dari pengamatan jumlah kematian larva Aedes aegypti setiap 24 jam. Dosis tertinggi yang dapat membunuh larva Aedes aegypti adalah $20 \mathrm{~g} / \mathrm{L}$.

Kata kunci: biolarvasida, rambut jagung, jentik, Aedes aegypti

\section{INTRODUCTION}

Dengue hemorrhagic fever (DHF) is still a serious health problem in the community because of the rapid spread of the disease, its relatively high mortality rate, and its potential to cause outbreaks or Kejadian Luar Biasa (KLB) which have a big impact on the economy and quality of life of the community. Stagnant water and dirty environments are the main nests of
Aedes aegypti mosquitoes, and are ideal breeding grounds that aid with the fertility of these mosquitoes. The incidence of dengue fever in the Indonesian population in 2015 was 50.75 per 100,000 population. This figure is up from the previous year, which was 39.8 per 100,000 population in 2014 (Sukohar, 2014).

The main vector for dengue fever is Aedes aegypti, which is an anthropophilic species suited to urban environments and 
often breeds in bodies of standing water. Transmission of the dengue virus to humans occurs through the bite of infected female mosquitoes, which usually bite during the daytime. An effective vaccine to provide protection against four dengue virus serotypes (DEN-1, DEN2, DEN-3 and DEN-4) has not been found. Therefore, control efforts often use the vector directly as a target in reducing dengue cases. Draining the bathtub is one of the efforts to control dengue mosquitoes (Sukohar, 2014)

In Indonesia, this dengue control is still quite difficult to manage because there are some areas that are still difficult to keep hygiene, thus presenting its own challenges for the population to carry out the $3 \mathrm{M}$ movement. In these areas, larvicides can be an alternative in overcoming the emergence of dengue vector mosquito breeding sites. Vector control depends on the use of insecticides applied to mosquito larvae. Larvicides such as organophosphate temephos have been widely used in public health programs. Insecticide material such as organophosphate temephos has been implemented in public health programs and has high effectiveness in reducing the number of mosquito vectors in the community. However, they can have a resistant impact on the vector because of their repeated use. In order to improve options that can be used in public health, larvicides are needed to avoid this problem. The ideal insecticide must be effective, efficient, environmentally friendly, and does not have a high toxicity effect on nontarget organisms (Sukohar, 2014)

Vaccines to prevent dengue are still in the research stage and effective drugs for dengue have not yet been found. Efforts to prevent or control DHF are currently done by fighting Aedes aegypti mosquitoes. The Aedes aegypti mosquito is a species that breeds in clean water reservoirs inside and outside the home. Therefore, the spread of mosquitoes must be controlled starting from the development of the stage of eggs, larvae, pupae, and adult mosquitoes. Vector control at larval age can be done by biological means using natural enemies or by chemical means using the chemical effect of larvicide (Kadorrohman, 2016)

There are four vector control methods, one of which is a biological control method using natural ingredients. The use of plants to control insect pests has been widely used by traditional societies of ancient times. An example of this is lemongrass oil, which has been widely used as an insect repellent because of the secondary metabolites it produces. This natural larvicide seized the attention of researchers to continue to develop studies of plant-based insecticides that can be used as vector controllers for Aedes aegypti. Plantbased insecticides have made significant contributions to new alternatives in improving public health, especially in reducing the number of diseases caused by mosquito vectors. Given the lack of information about plant extracts used as insecticides, this paper reviews some of the results of natural larvicidal activity research aimed at controlling the dengue virus for alternative seekers (Rochmat, dkk 2017).

The use of insecticides as larvicides is the most common method used by the community to control vector growth at larval age. The insecticide that is often used in Indonesia is Abate. Repeated use of chemical insecticides can increase the risk of contamination of pesticide residues in water, especially drinking water (Rochmat, Bahiyah and Adiati, 2017). On the other hand, the high cost of using chemical pesticides and the emergence of resistance from various species of mosquitoes become vectors of disease. (Ismatullah A, Kurniawan B, Wintoko R, 2011) A more effective and simple method of controlling DHF mosquitoes is to use plant larvicides (biolarvicides). Biolarvicides are able to kill mosquito larvae in puddles in the home environment more safely since they do not contain harmful chemicals. In addition, biolarvi cides are considered better than synthetic larvicide because they have unstable properties, making them easier to 
degrade naturally (Rochmat, Bahiyah and Adiati, 2017).

Zea mays L., better known as corn, is a plant that is widely known to the public. This plant is widespread, especially in Java, at an altitude of 200 meters above sea level. Parts of the corn plant have been widely used by the community as traditional medicine. One of the parts used is corn silk, which is a waste of the food industry. Corn silk water extracts show positive results on several components of secondary metabolites, which are very useful for human life. One of their uses is larvicide.

Indonesia has a variety of flora that can be used as a source of insecticides for disease vector control, and one that can be utilized is corn silk (Zea mays). Corn silk contains saponins, tannins, and flavonoids. These chemical compounds are larvicidal. Saponins play a role in reducing the activity of digestive enzymes and absorption of food, while flavonoids can inhibit the eating of insects and toxic. Tannins can reduce the ability to digest food by reducing the activity of digestive enzymes (proteases and amylases), while alkaloids act as stomach poisons. Stomach poisoning can cause digestive system disorders in Aedes aegypti larvae, so the larvae fail to grow, and die (Pamungkas dkk, 2015).

Based on the description above, a problem arises, namely whether corn silk extract (Zea mays) has potential as a biolarvicide against dengue vector larvae (Aedes aegypti). The purpose of this study was to determine the potential of corn silk extract (Zea mays) as a biolarvicide against dengue vector larvae (Aedes aegypti).

\section{METHODS}

The study was conducted at the biochemical laboratory of STIKes Ngudia Husada Madura in August 2019. Hair was obtained from an agricultural center in the Bangkalan district. As many as 1,000 Aedes aegypti larvae were obtained from the East Java provincial Health Office divided into 200 larvae to five treatment groups

Corn silk was taken from the inside of the corn that was still covered by cornstalk. This is because unexposed corn silk still contains many natural compounds. Corn silk was then air dried until the corn silk dried. Corn silk was not dried directly by sun exposure because it would have damaged the structure and phytochemical content contained in corn silk. After the corn silk was dried, it was blended to get a simplicia that was ready to be extracted. The process of blending corn silk aimed to increase the cross-sectional area of corn silk in order to ease the extraction of the phytochemical content in corn silk. Simplisia corn silk was then macerated using 96\% ethanol solvent for three days, in which the solvent was replaced every day.

Solvents are an important component in the process of extracting secondary metabolites. The process of separating secondary metabolites is carried out using a solvent that has properties similar to the compound to be extracted. Separating compounds is done by dissolving them, which means that the solvent used must have a polarity close to the polarity of the compound to be extracted (Maghfiroh, 2014)

Researchers chose the ethanol solvent for the extraction process because alcohol group compounds such as ethanol are very good solvents and can extract polar or nonpolar compounds. Ethanol has two groups with different levels of polarity, namely the polar hydroxyl group and the nonpolar alkyl group. The existence of these two groups in ethanol allows it to be used to extract compounds with different levels of polarity (Kristiani, 2014). Ethanol is inert, which means ethanol does not react with the components contained in simplicia. Ethanol also has a low boiling point, which makes it easy to manage in the process of separation or extraction (Susanti et al., 2012) 
After the maceration stage was completed, the extract obtained was then evaporated on a vacuum rotary evaporator. This stage aimed to evaporate the remaining ethanol solvent present in the extract in order to obtain a pure extract without ethanol residue. The extracts were then collected in a glass container, and then a qualitative phytochemical test was conducted to ensure the presence of saponins and flavonoids. A flavonoid test was carried out by adding $2 \% \mathrm{NH} 3$ to the extract, and positive results were indicated by the presence of yellow deposits. To test the saponin, $5 \mathrm{~mL}$ of the extract was pipetted into a reaction tube where a stable foam was then formed.

The concentration of the extract used in this study was determined based on the results of tests conducted by Koraag, et al. (2016) at a ratio of 1:2:4:8. The highest concentration was $20 \mathrm{~g} / \mathrm{L}$ (concentration D). The extract concentration for concentrations $\mathrm{A}, \mathrm{B}$, and $\mathrm{C}$, were $2.5 \mathrm{~g} / \mathrm{L}, 5$ $\mathrm{g} / \mathrm{L}$, and $10 \mathrm{~g} / \mathrm{L}$, respectively. Water was used as a control. Tests were carried out by observing deaths that occured in Aedes aegypti larvae after 24 hours of treatment in three replications.

This study has been declared to have passed ethical clearance by the Health Research Ethics Commission of STIKes Ngudia Husada Madura with the code: 141/KEPK STIKES-NHM/EC/VI/2019.

\section{RESULTS}

Tests were carried out by observing deaths that occured in Aedes aegypti larvae after 24 hours of treatment. In the first, second, and third test, the biolarvicide used was not replaced. From the three tests carried out, Aedes aegypti mosquito mortality was obtained at the four levels of corn extract extract given as shown in Table 1.
Table 1. Number of Death of Aedes aegypti Larvae After 24 Hours of Treatment.

\begin{tabular}{lllccc}
\hline \multirow{2}{*}{$\begin{array}{c}\text { Replikasi } \\
\text { Ke }\end{array}$} & \multicolumn{5}{c}{ Kelompok } \\
\cline { 2 - 6 } & A & B & C & D & K \\
\hline I & $\mathbf{1 0}$ & $\mathbf{2 3}$ & $\mathbf{3 3}$ & $\mathbf{5 1}$ & $\mathbf{0}$ \\
\hline II & $\mathbf{1 2}$ & $\mathbf{2 0}$ & $\mathbf{2 9}$ & $\mathbf{4 1}$ & $\mathbf{0}$ \\
\hline III & $\mathbf{1 2}$ & $\mathbf{2 2}$ & $\mathbf{3 1}$ & $\mathbf{4 7}$ & $\mathbf{0}$ \\
\hline Jumlah & $\mathbf{3 4}$ & $\mathbf{6 5}$ & $\mathbf{9 3}$ & $\mathbf{1 3 9}$ & $\mathbf{0}$ \\
\hline Rata - Rata & $\mathbf{1 1}$ & $\mathbf{2 2}$ & $\mathbf{3 1}$ & $\mathbf{4 6}$ & $\mathbf{0}$ \\
\hline Persentase & $\mathbf{2 2 , 6}$ & $\mathbf{4 3 , 3}$ & $\mathbf{6 2}$ & $\mathbf{9 2 , 6}$ & $\mathbf{0}$ \\
$(\%)$ & & & & &
\end{tabular}

Description :

Group A: corn germ extract concentration (2.5 $\mathrm{g} / \mathrm{L})$

Group B: concentration of corn extract $(5 \mathrm{~g} / \mathrm{L})$ Group C: concentration of corn extract (10 $\mathrm{g} / \mathrm{L})$

Group D: corn silk extract concentration of (20 $\mathrm{g} / \mathrm{L})$

Group K: concentration of corn silk extract (0 $\mathrm{g} / \mathrm{L})$

A graph illustrates the average number of larval mortalitys in each treatment group based on the results shown in Table 1.

\section{GRAFIK JUMLAH KEMATIAN LARVA}

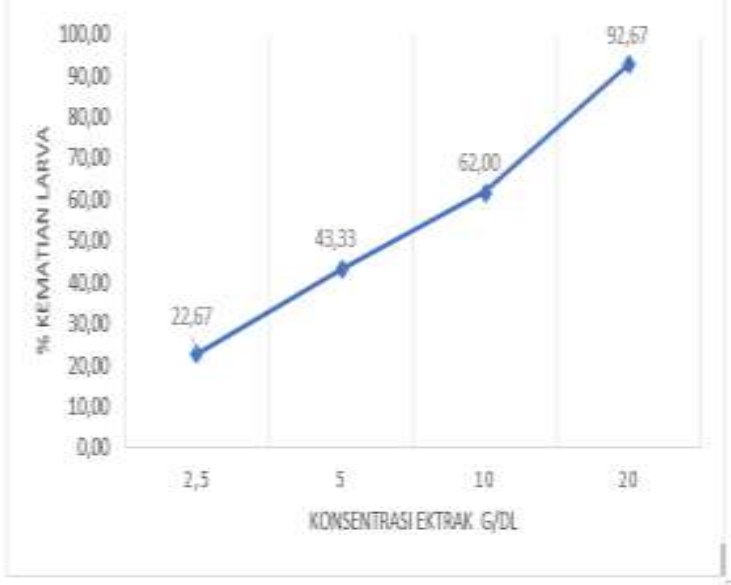

The test results of the phytochemical extracts of corn silk are as shown in Table 2. 
Table 2. Qualitative Phytochemical Test Results of Corn Hair Extract

\begin{tabular}{lll} 
Uji & Hasil & Keterangan \\
\hline \multirow{2}{*}{ Flavonoid } & Terbentuk & + \\
& Endapan & \\
& Kuning & \\
\hline
\end{tabular}

Saponin $\begin{aligned} & \text { Terbentuk } \\ & \text { busa }\end{aligned}$

The sign (+) indicates there are compounds in the extract

The sign (-) indicates there is no compound in the extract

Table 2 shows that the results of the phytochemical screening tests were positive. It indicates that the corn silk extract contains flavonoids and saponins that are thought to be beneficial as biolarvicides to kill Aedes aegypti larvae.

\section{DISCUSSION}

Table 2 shows that the corn silk extract obtained flavonoids and saponins. The graph above also indicates that the increase in the concentration of corn silk extract caused an increase in the number of Aedes aegypti larval mortality with an extract concentration of $20 \mathrm{~g} / \mathrm{L}$.

The average percentages of larval mortality after 24-hour treatment was $0 \%$ in the control group, $22.67 \%$ at an extract concentration of $2.5 \mathrm{~g} / \mathrm{L}, 43.33 \%$ at an extract concentration of $5 \mathrm{~g} / \mathrm{L}, 62 \%$ at an extract concentration of $10 \mathrm{~g} / \mathrm{L}$, and $92.67 \%$ at an extract concentration of $20 \mathrm{~g} / \mathrm{L}$. In group $\mathrm{K}$, no larval mortality was found, whereas in groups A, B, C, and D larval mortality occurred. This shows that corn silk extract does have a larvicidal effect. Figure 4.1 also shows that different concentrations of corn silk extract have different larvicidal power, where the higher the concentration, the more the number of larvae that die.

A laboratory guideline was issued in 2005 regarding the field of larvicidal testing by establishing standard larvicidal testing procedures (World Health Organisation (WHO), 2005). In testing, a potential compound such as an insecticide must be compared with other insecticides. Until now, the WHO has not set standard criteria in determining natural larvicidal activity, so many authors determine their own characteristics for the potential of natural product larvicides.Corn silk extraction was done using the maceration method. The filtrate was separated, then dried with a rotary evaporator at a temperature to form a thick ethanol extract. This thick ethanol extract was partitioned using ethanol and ethyl acetate solvents. The result of the partition was thickened again with a rotary evaporator to form a thick ethanol fraction extract and a thick extract of ethyl acetate fraction. The drying process with this method caused all the solvents to evaporate at their boiling point, and it wa s removed without damaging the content of the compounds in the extract(Antang et al., 2015).

The compounds extracted by ethanol are polar and semi-polar compounds, such as secondary metabolites of flavonoid, alkaloid, and natural material groups which are bound to glycosides, while the compounds extracted by nhexane are nonpolar compounds such as lipids, steroids and tannins. Polar ethyl acetate solvents include Alkaloids,Flavonoids, and Glycosides. Ethanol and ethyl acetate fractions were chosen for the toxicity test because the extract results were more specific to the group of compounds they obtained (Antang et al., 2015)

The mechanism of larval mortality is caused by active substances that enter the body of the larvae that interfere with the larval digestive system. This active substance will also inhibit the taste receptors in the mouth area of the larvae, which causes the larvae to fail to get a taste stimulus, thus they are unable to recognize their food, which eventually leads to starvation until death. Eventually, the larvae will die and settle to the bottom or float on 
the surface of the test solution (Antang et al., 2015).

Another mechanism caused by the death of active larvae into the body of the larvae will disrupt the digestive organs of larvae and dissolve lipin in the body of the larva. Eventually, the larvae will die and break down, making the test solution turbid, while some intact larvae bodies will float on the surface of the test solution (Antang et al., 2015)

The chemical constituents of corn silk which act as larvicides are saponins and flavonoids. The workings of these chemical compounds are as stomach poisons that can cause interference with the digestive system of larvae and inhibit the performance of the growth hormone (juvenile hormone). Stunted juvenile hormone growth in mosquito larvae can cause death (Rochmat dkk, 2017).

. Saponins have a bitter and sharp taste and can cause stomach irritation when eaten. Saponins are soapy surface active compounds and can be detected based on their ability to form foam if shaken in water and to monolize blood cells. Saponins can damage cell membranes and disrupt insect metabolic processes, while polyphenols act as insect digestion inhibitors. Some saponins work as antimicrobials. Saponin works as an antibacterial by disrupting the stability of bacterial cell membranes, causing bactericidal cells. Flavonoids are known to have antioxidant and teratogenic activity. Flavonoids play an important role in plants by forming yellow, red or blue pigments in the petals. Flavonoids also have anti microbial and insecticidal activities (Antang et al., 2015)

The mechanism of larvicide entry is through the throat, which is part of the larvae body that can absorb larvicides in large numbers. Ethanol extract can work as larvicidal poison by penetrating the larva's body wall, which is semipermeable to the compounds being passed through, resulting in the poison entering the epidermal cells in the process of changing the skin. Beside that, it can also enter through the digestive tract as a stomach poison. Toxic compounds that enter the body of an insect can cause a decrease in the rate of insect growth. Death has also been suspected to be caused by insects' failure to respond to food because it contains secondary metabolites. If the larvae eat foods that contain toxic oleochemical compounds, then the larvae do not reach the weight required to develop into pupa because of their metabolism rate and secretion of digestive enzymes, thus causing reduced energy for growth.

Another entry point is the respiratory tract. Insecticides that affect the respiratory system of insects play a role in inhibiting respiratory enzymes, specifically the electron transport system and oxidative phosphorylation. Inhibition of the electron transport system is characterized by paralysis and ends with death due to bioactive compounds attacking the NPNH and NADH electron transport processes (Rochmat, Bahiyah and Adiati, 2017).

Larval mortality is caused by the content of chemical compounds in the leaves of the week in the form of terpenoids, flavonoids, alkaloids, tannins, coumarin, and saponins. These compounds are plant defense chemical compounds included in secondary metabolites produced in plant tissues and can be toxic and function as stomach and respiratory poisons. The existence of terpenoids in corn yam has potential as a food barrier in a number of insects. The content of secondary metabolites in the ethanol extract of corn silk simultaneously inhibited larvae of Aedes aegypti mosquitoes (Rochmat, dkk, 2017).

The larvicidal effect of corn silk is thought to be from the citronella content found in corn silk extract. Flavonoids have poisonous properties (desiscant), which function as contact poisons that can cause death due to continuous loss of fluid. Flavonoids work by inhibiting the enzyme acetylcholinesterase by phosphorylation of serine amino acids in the asteratic center of the enzyme concerned. Symptoms of poisoning, due to the accumulation of 
acetylcholine which causes special poisoning are characterized by disorders of the central nervous system, seizures, respiratory paralysis, and death (Antang et al., 2015)

The high mortality of test larvae could have been caused by the presence of chemical compounds in corn silk extract, which play a role in the growth and development of larvae. Various types of plants have been known to contain bioactive compounds such as phenylpropane, terpenoids, alkaloids, acetogenin, steroids and tannins that act as insecticides. The compounds contained in orange peel include limonoids, saponins and tannins. Saponin acts as an inhibitor to eat on insects (antifeedants) and works to wither nerves in the respiratory system of insects, while tannins can influence the failure of moulting in larvae, causing them to die before developing into pupae (Riyadi, 2017)

Saponins are insect poisons that can reduce the activity of digesting enzymes. Tannins play a role in reducing the ability to digest food by reducing the activity of digestive enzymes (proteases and amylases) and disrupting intestinal protein activity. Flavonoids are inhibiting eating insects and are also toxic (Riyadi, 2017).

Saponins can bind free plant sterols in the digestion of food. Sterols act as precursors to the hormone ecdysone This hormone plays a role in stimulating growth and causing the epidermis to secrete a new cuticle which causes the skin peeling process to begin, therefore by decreasing the amount of free plant sterols the skin replacement process in insects will be disrupted (Abdiana and Anggraini, 2017).

Saponins can enter the body of larvae through the mouth of the larvae (inedible larvae). Saponins have a mechanism of action that can reduce the activity of protease enzymes and food absorption. This can cause energy for larval growth to be reduced so that larval growth is inhibited and the larvae eventually die. In the insect's nervous system, between neurons and other cells including muscle cells, there is a synaptic gap. Acetylcholine serves to deliver impulses from nerve cells to muscle cells through synapses. After the impulse is delivered, the impulse delivery process is stopped by the enzyme acetylcholinesterase, which is then broken down into acetyl co-A and choline to empty the synapse for the next delivery. Flavonoids are plant defense compounds that are toxic and work as respiratory poisons. Flavonoids enter the body of larvae through the respiratory system and cause damage resulting in the larvae not being able to breathe and eventually dying. Irregular larvae body position changes are caused by flavonoid compounds. This is due to the ingress through the siphon, which can cause damage. As a result, the larvae must align their position with the water surface to make it easier to take in oxygen (Nurhaifah and Sukesi, 2014).

Flavonoids have a way of working to inhibit the power of eating larvae (antifeedant) by inhibiting the taste receptors in the mouth area of the larvae, which will cause the larvae to fail to get a taste stimulus. Therefore, the larvae are unable to recognize food. Low feeding activity in larvae causes energy for larval development to decrease, thereby inhibitng the growth process (Astriani and Widawati, 2016).

\section{CONCLUSION}

Based on the research that has been done, it can be concluded that the average percentage of larval mortality after 24-hour treatment is $0 \%$ in the control group, $22.67 \%$ at the extract concentration of 2.5 $\mathrm{g} / \mathrm{L}, 43.33 \%$ at the extract concentration of $5 \mathrm{~g} / \mathrm{L}, 62 \%$ at the extract concentration of $10 \mathrm{~g} / \mathrm{L}$, and $92.67 \%$ at the extract concentration of $20 \mathrm{~g} / \mathrm{L}$. No larval mortality was found in group $\mathrm{K}$, whereas in groups $\mathrm{A}$, $\mathrm{B}, \mathrm{C}$, and $\mathrm{D}$ larvae mortalities were observed. Corn silk extract can be used as a biolarvicide, and $20 \mathrm{~g} / \mathrm{dL}$ extract was the 
most effective to kill larvae as seen from the largest percentage of larval mortality.

\section{REFERENCES}

Abdiana, R. And Anggraini, D. I. (2017) 'Rambut Jagung ( Zea Mays L .) Sebagai Alternatif Tabir Surya Corn Silk ( Zea Mays L .) As An Alternative To Sunscreen', 7(November), Pp. 31-35. https://Doi.Org/8421/1/1741-24481-PB.

Antang, P. Et Al. (2015) 'Efektivitas Larvasida Ekstrak Kulit Buah Jeruk Nipis ( Citrus Aurantifolia ) Dalam Membunuh Jentik Nyamuk Aedes Sp ( Studi Di Daerah Epidemi DBD Di Wilayah Kerja', Jurnal Kesehatan Masyarakat Nasional, 9, P. 3.

Astriani, Y. And Widawati, M. (2016) 'Potensi Tanaman Di Indonesia Sebagai Larvasida Alami Untuk Aedes Aegypti Potential Plant In Indonesia As Natural Larvicides For Aedes Aegypti', 8(2), Pp. 37-46. https://Doi.Org/10.22435/Spi.V8i2. 6166.37-46

Ismatullah A, Kurniawan B, Wintoko R, S. E. (2011) 'Uji Efektivitas Larvasida Ekstrak Daun Binahong (Anredera Cordifolia (Ten.) Steenis) Terhadap Larva Aedes Aegypti Instar III', Fakultas Kedokteran Universitas Lampung, Pp. 1-9.

Kadorrohman, L. L. \& A. (2016) 'Efektivitas Biolarvasida Ekstrak Etanol Limbah Penyulingan Minyak Akar Wangi ( Vetiveria Zizanoides ) Terhadap Larva Nyamuk Aedes Aegypti , Culex Sp ., Dan Anopheles Sundaicus', (December).

Koraag, M. E., Anastasia, H. And Isnawati, R. (2016) 'Efikasi Ekstrak Daun Dan Bunga Kecombrang ( Etlingera Elatior ) Terhadap Larva Aedes Aegypti', 8(September), Pp. 63-68. Kristiani, V. \& F. I. H. (2014) Pengaruh Konsentrasi Etanol Dan Waktu
Maserasi Terhadap Perolehan

Fenolik, Flavonoid, Dan Aktivitas Antioksidan Ekstrak Rambut Jagung. Universitas Katolik Widya Mandala.

Maghfiroh (2014) Uji Aktivitas Antibakteri Ekstrak Bunga Melati Terhadap Pertumbuhan Bakteri Staphylococcus Aureus ATCC 25923 Dan Shigella Flexneri ATCC 12022. Universitas Islam Negeri Sunan Kalijaga Yo.

Nurhaifah, D. And Sukesi, T. W. (2014) 'Efektivitas Air Perasan Kulit Jeruk Manis Sebagai Larvasida Nyamuk Aedes Aegypti Effectivity Of Sweet Orange Peel Juice As A Larvasides Of Aedes Aegypti Mosquito', Pp. 207-213.

Pamungkas, R. W., Syafei, N. S. And Soeroto, A. Y. (No Date) 'Perbandingan Efek Larvasida Minyak Atsiri Daun Cengkeh ( Syzygium Aromaticum L.) Varietas Zanzibar Dengan Temephos Terhadap Larva Nyamuk Aedes Aegypti Abstrak', 4(1), Pp. 0-5. http://Dx.Doi.Org/10.7454/Psr.V3i 3.3566

Riyadi, Z. (2017) 'Artikel Penelitian Uji Efektivitas Ekstrak Etanol Biji Rambutan ( Nephelium Lappaceum L .) Sebagai Larvasida Alami Pada Larva Nyamuk Aedes Aegypti', Jurnal FK Unand, 7(2), Pp. 233239.

https://Doi.Org/10.25077/Jka.V7.I2.P 233-239.2018

Rochmat, A., Bahiyah, Z. And Adiati, F. (2017) 'Pengembangan Biolarvasida Jentik Nyamuk Aedes Aegypti Berbahan Aktif Ekstrak Beluntas ( Pluchea Indica Less . )', (January). Doi: 10.14710/Reaktor.16.3.103-108. https://Doi.Org/10.14710/Reaktor.16. 3.103-108

Sukohar, A. (2014) 'Demam Berdarah (DBD)', Medula Unila, 2, Pp. 1-15. http://Dx.Doi.Org/10.22435/Jek.V1 6i1.5032.1-9 
Susanti, A. D. Et Al. (2012) 'Pemilihan Pelarut Untuk Ekstraksi Minyak Bekatul Dari Bekatul Varietas Ketan ( Oriza Sativa Glatinosa )', Simposium Nasional RAPI XI FT $U M S$, Pp. 8-14. Abdiana, R. And Anggraini, D. I. (2017) 'Rambut Jagung ( Zea Mays L .) Sebagai Alternatif Tabir Surya Corn Silk ( Zea Mays L.) As An Alternative To Sunscreen', 7(November), Pp. 3135. https://Doi.Org/8421/1/1741-
2448-1-PB.

Putri (2015) Ekstraksi Senyawa Fenolik Pada Kulit Ari Kacang Tanah ( Arachis Hypogaea L .) Menggunakan Irradiasi Microwave. Universitas Negeri Semarang.

World Health Organisation (WHO) (2005) Guidelines For Laboratory And Field Testing Of Mosquito Larvicides, World Health Statistics. 